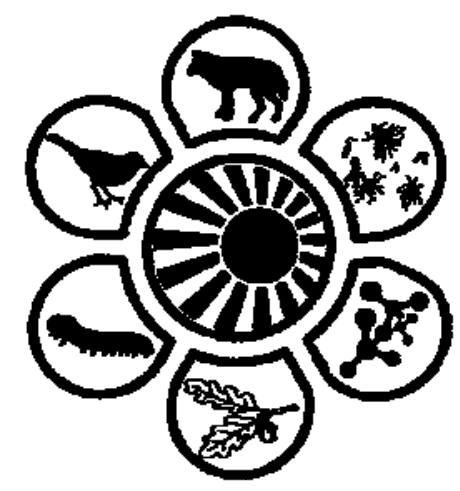

Вісник Дніпропетровського університету. Біологія, екологія.

Vìsnik Dnìpropetrovs'kogo unìversitetu. Seriâ Bìologiâ, ekologiâ

Visnyk of Dnipropetrovsk University. Biology, ecology.

Vìsn. Dnìpropetr. Unìv. Ser. Bìol. Ekol. 2015. 23(2), 230-235.

doi: $10.15421 / 011534$

ISSN 2310-0842 print

ISSN 2312-301X online

www.ecology.dp.ua

УДК 581.44(477.63)

\title{
Вплив викидів Придніпровської ТЕС м. Дніпропетровськ на анатомічні показники стебла дворічного пагона представників роду Tilia
}

\author{
3.В. Грицай, Л.В. Шупранова
}

Дніпропетровський наџіональний університет імені Олеся Гончара, Дніпропетровськ, Украӥна

Вивчено гістологічні характеристики стебла дворічного пагона представників роду Tilia за хронічної дії на деревні насадження викидів Придніпровської ТЕС м. Дніпропетровськ. У досліджених об'єктів на техногенно забрудненій ділянці встановлено зміни розмірів гістологічних елементів стебла, характер яких має видові відмінності. У T. platyphyllos Scop. i T. europaea L. за дії токсичних викидів ТЕС виявлено збільшення ширини первинної кори стебла та окремих їі складових (корка, коленхіми, корової паренхіми) та підтримання стабільних розмірів вторинної кори та ії гістологічних елементів (твердого та м'якого лубу), а в $T$. europaеaтакож і радіуса деревини, що ми розглядаємо як показники відносної стійкості даних видів у техногенному середовищі. У T. cordata Mill. за дії токсикантів установлено збільшення ширини корка, корової паренхіми та загальної товщини первинної кори, що може забезпечувати певну толерантність рослин до несприятливих умов зростання. Разом із тим, у T. cordata у забрудненій зоні виявлено зменшення розмірів коленхіми, твердого лубу, м’якого лубу, нерівномірний розвиток шару деревини, що у сукупності може зменшувати механічну міцність стебла, порушувати пересування розчинів органічних речовин та елементів мінерального живлення по системі спеціалізованих провідних тканин, i, таким чином, підвищувати вразливість рослин даного виду на техногенних територіях. Запропоновано чутливі анатомічні показники стебла дворічного пагона лип як інформативні тестпараметри для застосування в моніторингу стану довкілля в умовах техногенезу.

Ключові слова: техногенне забруднення; липи; первинна кора; луб; деревина; серцевина

\section{Impact of emissions of Pridneprovsk TPP in Dnipropetrovsk on the anatomical indices of stem of two-year whip of the Tilia genus representatives}

\author{
Z.V. Gritzay, L.V. Shupranova \\ Oles Honchar Dnipropetrovsk National University, Dnipropetrovsk, Ukraine
}

The paper presents discussion of the results of studying the impact of environmental contamination because of emissions of Pridneprovsk TPP in Dnipropetrovsk city on the anatomical indices of stem of two-year whip of the Tilia genus representatives. Objects of study were T. platyphyllos Scop., T. europaea L. and T. cordata Mill. Material was collected in September 2015 on two sampling areas: experimental plot - tree plantations adjacent to Pridneprovsk TPP which emissions mainly comprise the pollutants such as sulfur dioxide, nitrogen oxides, particulate matter, with the share in total volume of emissions of the Plant being $67.3 \%, 18.7 \%, 13.3 \%$, respectively; control plot (conditionally clean) - territory of the Botanical garden of Oles Honchar Dnipropetrovsk National University. For research, two-year whips located in the apical portion of branches of the same order of branching were taken. Sections were made at the medium cross-line of the stem, and stained with the alcoholic solution of phloroglucinol. 30 sections for each species were measured on each sampling area. In the objects under study on technogenically contaminated area the changes in dimensions of histological elements of the stem were found and the nature of such changes had specific differences. T. platyphyllos and T. europaea under action of toxic emissions of TPP demonstrated the increase of total size of primary cortex of stem and width of its individual components (plug, collenchyma, cortex parenchyma), maintenance of stable dimensions of the bark and its histological elements (hard and soft bast), and in T. europaea the wood radius as well, which we considered as the indicators of relative stability of these species in technogenic environment. In T. cordata in the TPP emission zone we revealed the increase in the width of plug, cortex parenchyma, and total radius of primary cortex, which could provide certain toler-

Дніпропетровський національний університет імені Олеся Гончара, пр. Гагаріна, 72, Дніпропетровськ, 49010, Украӥна Oles Honchar Dnipropetrovsk National University, Gagarin Ave., 72, Dnipropetrovsk, 49010, Ukraine

Tel.: +38-095-477-21-53.E-mail: gritsaj.zoja@yandex.ru 
ance of plants of this species in the adverse conditions of growth. Together with it, for T. cordata on the contaminated area we established the decrease in size of collenchyma, hard bast, soft bast, uneven development of the layer of wood which in aggregate could reduce the mechanical strength of the stem, disrupt the flow of organic substances and mineral nutrients in the system of specialized conducting tissues, and consequently increase the vulnerability of these plant species on technogenic territories. Sensitive anatomical figures indices of the stem of two-year lime whips are suggested as informative test parameters for use in the environment status monitoring in the conditions of technogenesis.

Keywords: technogenic pollution; limes; primary cortex; bast; wood; pith

\section{Вступ}

Дніпропетровськ - один із найбільших промислових центрів Південного Сходу України. Левова частка від загальної кількості шкідливих речовин, що потрапляють у повітряний басейн міста від усіх зосереджених на його території підприємств, надходить від Придніпровської TEC (Striletz, 2014). У процесі очищення атмосфери, води, грунту від техногенних забруднювачів суттєва роль належить деревним насадженням. Вони успішно поглинають значну масу хімічних сполук, що надходять iз викидами промисловості, енергетики, автотранспорту тощо (Smit, 1985; Kulagin and Shagieva, 2005; Capuana, 2011). Разом із тим, рослини, виконуючи очистну функцію, піддаються негативній дії шкідливих речовин, що часто спричиняє зниження життєздатності деревних насаджень, які зазнають впливу промислових емісій (Skärby et al., 1989; Miller and McBride, 1999; Gritzay and Jusypiva, 2004; Gupta et al., 2009; Gritzay and Denisenko, 2011; Jusypiva, 2011; Petrova et al., 2014). Прогресуюче техногенне навантаження - один із домінуючих у комплексі природних і антропогенних чинників, що спричиняють виснаження та деградацію фітоценозів (Sergejchik, 1984; Smit, 1985; Dyrenkov et al., 1986; Cudin, 1996; Bobyliov et al., 2014).

Створення стійких зелених насаджень в умовах антропогенного навантаження потребує науково обгрунтованого підходу, важливість якого визначається й тим, що фітоценози безпосередньо впливають на просторову структуру інших компонентів біогеоценозів (Kulbachko et al., 2011; Pakhomov et al., 2011; Faly and Brygadyrenko, 2014). Для 3'ясування впливу промислових викидів на стан рослин необхідне проведення досліджень процесів їх росту та розвитку, які дають уявлення про пристосування або пошкодження в техногенному середовищі. Одним із критеріїв фізіологічного стану рослинного організму $є$ анатомічні показники пагонів, оскільки зміни їх гістологічних характеристик відображують фізіолого-біохімічні та ростові адаптивні процеси рослин (Alekseev, 1990; Jusypiva, 2006).

Анатомічні характеристики стебла в пагонах деревних і чагарникових рослин в умовах техногенного навантаження досліджували В.М. Гришко зі співробітниками у видів роду Populus (Grishko et al., 1997), В.П. Бессонова та T.I. Юсипіва у Robinia pseudoacacia L. i Gleditsia triacanthos L. (Bessonova and Jusypiva, 2001), Д.В. Веселкін у Abies sibirica Ledeb. та Picea obovata Ledeb. (Veselkin, 2004), T.I. Юсипіва у представників роду Fraxinus (Jusypiva, 2005; 2006), Ж. Ріконен зі співавторами у Betula papyrifera Marshall (Riikonen et al., 2010), О.А. Невєрова зі співробітниками у B. pendula Roth. (Neverova et al., 2013), T.I. Юсипіва та 3.B. Грицай y Caragana arborescens Lam. (Jusypiva and Gritzay, 2014) та інші.
У системі зеленого будівництва важливе місце належить видам роду Tilia. Високі декоративні характеристики лип роблять їх привабливим об'єктом для озеленення міських територій. Однак широке використання зелених насаджень із залученням лип, організація та ведення господарства в них потребує глибокого знання їх ботанічних і біолого-екологічних особливостей. Обираючи асортимент видів для озеленення територій iз високим рівнем антропогенного навантаження, зокрема, необхідно враховувати здатність рослин поглинати шкідливі сполуки, зберігати свої естетичні якості в умовах забрудненого середовища, а також їх стійкість у конкретних екологічних умовах (Grishko and Mashtaler, 2009; Jusypiva and Korostylova, 2015). У літературних джерелах є дані про вплив техногенного забруднення на стан асиміляційного апарату представників роду Tilia (Ponomar'ova and Bessonova, 2009; Krupenko and Kapelush, 2014), на характеристики флоральної сфери лип (Jusypiva and Korostylova, 2015), насіннєву продуктивність (Erofeeva, 2014). Дослідження чутливості гістологічних показників пагона видів роду Tilia до техногенного навантаження в умовах степового Придніпров'я практично відсутні.

Мета даної роботи - оцінити вплив забруднення довкілля викидами Придніпровської ТЕС м. Дніпропетровськ на анатомічні показники стебла дворічного пагона представників роду Tilia.

\section{Матеріал і методи досліджень}

Об'єкти дослідження - липа широколиста (Tilia platyphyllos Scop.), європейська (T. europaea L.) та дрібнолиста (T. cordata Mill.). Проби відбирали у вересні 2015 р. у двох точках: дослідна ділянка - деревні насадження, що прилягають до Придніпровської ТЕС м. Дніпропетровськ, у викидах якої основні забруднювальні речовини - це діоксид сірки, оксиди азоту, тверді домішки, частка яких до загального обсягу викидів даного об'єкта складає 67,3\%, 18,7\%, 13,3\% відповідно (Striletz, 2014); контрольна ділянка (умовно чиста) - територія Ботанічного саду Дніпропетровського національного університету імені Олеся Гончара, де, за даними міської санепідемстанції, концентрації забруднювальних речовин не перевищують ГДК.

На обох пробних ділянках для кожного виду 3 декількох модельних дерев відбирали по 30 дворічних пагонів - тих, що примикали до однорічного верхівкового пагона гілок однакового порядку галуження. Фіксацію відібраного матеріалу здійснювали в 70\% етанолі. Поперечні зрізи готували із середньої частини стебла дворічного пагона. Для реакції на здерев'яніння зрізи забарвлювали 1\% спиртовим розчином флороглюцину (Permjakov, 1988). Розміри гістологічних елементів стебла вимірювали під мікроскопом за допомогою окулярмікрометра при збільшенні 7 х $40(0,65)$. Повторність 
досліду - 30 зрізів стебла для кожного виду з кожної пробної площі. Результати експерименту опрацьовані статистично. Розраховували середню арифметичну похибку, для порівняння вибірок використовували t-критерій Стьюдента з попередньою оцінкою розподілу вибірки на нормальність.

\section{Результати та їх обговорення}

В умовах хронічної дії на деревні насадження викидів TEC у представників роду Tilia виявлено зміни анатомічних показників стебла, характер яких має видові відмінності. На поперечному зрізі стебла дворічного пагона досліджених видів зовнішнім шаром тканин $є$ первинна кора. Оскільки покривній тканині належить важлива роль у захисті функціональних систем внутрішньої частини органа від несприятливих чинників довкілля, вивчення іiі гістологічних елементів в умовах техногенного навантаження становить суттєвий інтерес. Одержані дані свідчать, що в усіх досліджених об'єктів ширина первинної кори за впливу викидів ТЕС суттєво збільшується порівняно з контрольними рослинами. Найбільшою мірою товщина даного шару тканин у дослідному варіанті підвищується в $T$. platyphyllos (на $58,6 \%$ відносно контролю), менш суттєво - у T. еuropaea та T. cordata (на 25,0\% та на 14,6\% відповідно) (табл. 1).

Вплив викидів Придніпровської ТЕС на розміри гістологічних елементів первинної кори стебла

Табличя 1 дворічного пагона представників роду Tilia $(\mathbf{n}=\mathbf{3 0})$

\begin{tabular}{|c|c|c|c|c|c|}
\hline \multirow{2}{*}{$\begin{array}{c}\text { Гістологічні } \\
\text { елементи }\end{array}$} & \multirow[t]{2}{*}{ Вид } & \multicolumn{2}{|c|}{$\begin{array}{c}\text { Ширина гістологічних елементів } \\
\text { по радіусу поперечного зрізу стебла, мкм }\end{array}$} & \multirow{2}{*}{$\begin{array}{c}\text { Частка від } \\
\text { контролю, \% }\end{array}$} & \multirow{2}{*}{$\begin{array}{c}\mathrm{t} \\
\left(\mathrm{t}_{0,05}=2,05\right)\end{array}$} \\
\hline & & контрольна ділянка & дослідна ділянка & & \\
\hline \multirow{3}{*}{ Первинна кора } & T. platyphyllos & $169,3 \pm 2,28$ & $268,5 \pm 3,02$ & 158,6 & 26,24 \\
\hline & T. europaea & $227,1 \pm 2,16$ & $260,2 \pm 2,89$ & 114,6 & 9,02 \\
\hline & T. cordata & $165,2 \pm 1,92$ & $206,5 \pm 2,36$ & 125,0 & 13,60 \\
\hline \multirow{3}{*}{ Корок } & T. platyphyllos & $49,6 \pm 1,66$ & $82,6 \pm 1,84$ & 166,5 & 13,32 \\
\hline & T. europaea & $74,3 \pm 1,43$ & $86,7 \pm 1,52$ & 116,7 & 5,93 \\
\hline & T. cordata & $53,7 \pm 1,74$ & $82,6 \pm 2,06$ & 153,8 & 10,72 \\
\hline \multirow{3}{*}{ Коленхіма } & T. platyphyllos & $49,6 \pm 2,09$ & $66,1 \pm 1,86$ & 133,3 & 5,89 \\
\hline & T. europaea & $70,2 \pm 1,61$ & $78,5 \pm 1,74$ & 111,8 & 3,50 \\
\hline & T. cordata & $66,1 \pm 1,13$ & $62,0 \pm 1,04$ & 93,8 & 2,57 \\
\hline \multirow{3}{*}{ Корова паренхіма } & T. platyphyllos & $74,3 \pm 1,88$ & $115,6 \pm 2,27$ & 155,6 & 14,01 \\
\hline & T. europaea & $82,6 \pm 1,94$ & $99,1 \pm 2,05$ & 120,0 & 5,85 \\
\hline & T. cordata & $49,6 \pm 1,43$ & $66,1 \pm 1,98$ & 133,3 & 6,76 \\
\hline
\end{tabular}

Аналіз впливу техногенного забруднення на розміри окремих складових первинної кори стебла свідчить, що в досліджених порід за дії токсичних викидів ТЕС змінюється ширина всіх гістологічних елементів даної покривної тканини. Зовнішній шар первинної кори - це корок. Його розміри за дії фітотоксикантів суттєво збільшуються у стеблі $T$. platyphyllos і $T$. cordata (на $66,5 \%$ та 53,8\% порівняно 3 контролем). У T. europaea ширина фелеми також у дерев дослідної ділянки збільшується відносно контролю, однак меншою мірою, ніж у двох попередніх видів (на 16,7\%) (табл. 1).

Оскільки в онтогенезі стінки клітин фелеми значно потовщуються, просочуються суберином, втрачається живий вміст клітин, після чого шар корка стає непроникним для газів і рідин. Збільшення ширини даної тканини у стеблі вивчених видів лип в умовах техногенезу може підвищувати захист розташованих глибше структур стебла від токсичних хімічних речовин.

Наступними після корка шарами первинної кори досліджуваних органів лип $\epsilon$ коленхіма та корова паренхіма. Згідно з одержаними результатами, у T. platyphyllos i $T$. europaea в контрольному варіанті частка коленхіми у первинній корі стебла дворічного пагона менша, ніж корової паренхіми. Така ж закономірність характерна і для рослин промислового майданчика. За дії токсичних викидів ТЕС товщина обох шарів (механічної тканини та паренхіми) в обох видів збільшується порівняно $з$ контрольним варіантом (табл. 1). У $T$. cordata у чистій зоні, навпаки, частка механічної тканини більша, ніж корової паренхіми. За дії техногенних емісій розміри коленхіми в даного виду зменшуються порівняно з контролем (на 6,2\%), а корової паренхіми - збільшуються (на $33,3 \%$, унаслідок чого співвідношення вказаних шарів покривної тканини змінюється на користь паренхіми (табл. 1). Вважаємо, що зниження розмірів механічної тканини T. cordata у зоні промислових викидів може зменшувати механічну міцність стебла, що $є$ додатковим негативним фактором у несприятливих умовах зростання.

У досліджуваних органах під первинною залягає вторинна кора. Вона представлена елементами твердого та м'якого лубу. На поперечному зрізі стебла суцільні кільцеві шари м'якого лубу чергуються 3 розривними, також кільцевими рядами трапецієвидних ділянок твердого лубу. Характер зміни розмірів вторинної кори та ії складових елементів за дії промислових викидів у досліджених порід має видову специфічність. У T. platyphyllos i T. europaea загальна товщина вторинної кори практично не відрізняється у рослин контрольної та дослідної ділянок. Відмінність розмірів окремих гістологічних складових флоеми (м'якого лубу та механічної тканини) у дерев проммайданчика та умовно чистої зони також недостовірна (табл. 2). Утримання стабільних розмірів м'якого лубу стебла T. platyphyllos i $T$. europaea в умовах техногенного впливу дозволить цим видам підтримувати на належному рівні пересування розчинів органічних речовин по системі ситоподібних трубок флоеми, а розмірів твердого лубу зберігати механічну міцність стебла. 
Вплив викидів Придніпровської ТЕС на розміри гістологічних елементів центрального циліндра стебла дворічного пагона представників роду Tilia $(\mathbf{n}=\mathbf{3 0})$

\begin{tabular}{|c|c|c|c|c|c|}
\hline \multirow{2}{*}{$\begin{array}{l}\text { Гістологічні } \\
\text { елементи }\end{array}$} & \multirow[t]{2}{*}{ Вид } & \multicolumn{2}{|c|}{$\begin{array}{c}\text { Ширина гістологічних елементів по радіусу } \\
\text { поперечного зрізу стебла, мкм }\end{array}$} & \multirow{2}{*}{$\begin{array}{c}\text { Частка від } \\
\text { контролю, \% }\end{array}$} & \multirow{2}{*}{$\begin{array}{c}\mathrm{t} \\
\left(\mathrm{t}_{0,05}=2,05\right)\end{array}$} \\
\hline & & контрольна ділянка & дослідна ділянка & & \\
\hline \multirow{3}{*}{ Вторинна кора } & T. platyphyllos & $268,5 \pm 8,16$ & $260,2 \pm 6,69$ & 96,9 & 0,79 \\
\hline & T. europaea & $371,7 \pm 7,81$ & $375,8 \pm 8,56$ & 101,1 & 0,35 \\
\hline & T. cordata & $219,0 \pm 5,82$ & $185,9 \pm 3,08$ & 84,9 & 5,08 \\
\hline \multirow{3}{*}{ Твердий луб } & T. platyphyllos & $150,2 \pm 4,12$ & $148,7 \pm 3,86$ & 99,0 & 0,37 \\
\hline & T. europaea & $247,8 \pm 7,24$ & $247,8 \pm 5,97$ & 100,0 & 0,00 \\
\hline & T. cordata & $107,4 \pm 2,38$ & $95,0 \pm 2,07$ & 88,5 & 3,94 \\
\hline \multirow{3}{*}{ М'який луб } & T. platyphyllos & $110,0 \pm 2,16$ & $107,4 \pm 2,23$ & 97,6 & 0,88 \\
\hline & T. europaea & $123,9 \pm 2,41$ & $119,8 \pm 2,83$ & 96,7 & 1,10 \\
\hline & T. cordata & $99,1 \pm 2,27$ & $82,6 \pm 1,69$ & 83,4 & 5,88 \\
\hline \multirow{3}{*}{ Деревина } & T. platyphyllos & $545,2 \pm 9,14$ & $425,4 \pm 11,21$ & 78,0 & 8,29 \\
\hline & T. europaea & $702,1 \pm 11,73$ & $718,6 \pm 12,44$ & 102,4 & 0,37 \\
\hline & T. cordata & $330,4 \pm 7,46$ & $338,7 \pm 6,81$ & 102,5 & 0,32 \\
\hline \multirow{3}{*}{ Серцевина } & T. platyphyllos & $478,8 \pm 8,67$ & $443,1 \pm 9,24$ & 92,5 & 2,82 \\
\hline & \begin{tabular}{|l|} 
T. europaea \\
\end{tabular} & $413,0 \pm 7,06$ & $371,7 \pm 8,32$ & 90,0 & 3,79 \\
\hline & T. cordata & $367,6 \pm 8,91$ & $268,5 \pm 7,29$ & 73,0 & 8,62 \\
\hline \multirow{3}{*}{$\begin{array}{l}\text { Стебло в цілому } \\
\text { (радіус) }\end{array}$} & T. platyphyllos & $1486 \pm 36,7$ & $1424 \pm 38,3$ & 95,8 & 1,17 \\
\hline & T. europaea & $1734 \pm 41,2$ & $1714 \pm 39,6$ & 98,8 & 0,35 \\
\hline & T. cordata & $1156 \pm 27,6$ & $1053 \pm 22,3$ & 91,1 & 2,90 \\
\hline
\end{tabular}

У T. cordata на техногенно забрудненій території ширина вторинної кори знижується на 15,1\% відносно контролю. Це відбувається за рахунок зменшення товщини як м'якого лубу, так і твердого (на 16,6\% та 11,5\% порівняно з контролем відповідно) (табл. 2). Як бачимо, частка провідних елементів флоеми у цього виду в умовах проммайданчика знижується більшою мірою, ніж механічної тканини вторинної кори. Зменшення розмірів м'якого лубу стебла в T. cordata, яке спостерігається за дії токсичних викидів ТЕС, може спричинювати послаблення транспорту продуктів асиміляції 3 листків до інших органів і тканин, що може негативно позначатись на їх фізіологічній активності за несприятливих умов зростання. Зниження товщини твердого лубу може погіршувати його опорну функцію в стеблі.

Розмір деревини в умовах техногенного впливу знижується порівняно із цим показником в умовно чистій зоні в $T$. platyphyllos (на 22,0\%) і практично не відрізняється від контролю в T. europaea (табл. 2). У T. cordata за дії викидів ТЕС деревина у стеблі дворічного пагона утворює нерівномірно розширене кільце, розмір якого по радіусу стебла на одних ділянках удвічі більший порівняно з іншими ділянками ксилеми на цьому самому зрізі. Тому для кожного зрізу визначали середнє значення ширини деревини із декількох їі ділянок і саме його брали до вибірки. Як видно 3 таблиці 2, даний показник у T. cordata не має достовірної відмінності між рослинами дослідного та контрольного варіантів. Однак вважаємо, що формування нерівномірних шарів ксилеми, яке спостерігається у цього виду в умовах проммайданчика, може несприятливо позначитись на пересуванні води та мінеральних речовин по системі провідних елементів ксилеми.

Центральну частину поперечного зрізу стебла займає серцевина. Її діаметр за дії фітотоксикантів зменшується відносно контролю в усіх досліджених об'єктів. У T. platyphyllos і T. europaea, можливо, зниження розмірів серцевини компенсує збільшення ширини первинної кори при практично однаковому радіусі стебла цих видів у контрольному та дослідному варіантах. У $T$. cordata в умовах техногенного впливу зменшується порівняно з контролем радіус як серцевини, так і стебла в цілому (табл. 2).

\section{Висновки}

В умовах хронічної дії на деревні насадження викидів TEC у представників роду Tilia виявлено зміни розмірів гістологічних елементів стебла дворічного пагона. В усіх досліджених видів у забрудненій зоні встановлене суттєве збільшення товщини первинної кори. Зміна окремих ії складових в умовах техногенезу має видові відмінності: у T. platyphyllos i T. europaea зростає ширина як захисних тканин кори (корка та коленхіми), так i корової паренхіми; у $T$. cordata збільшується розмір фелеми та корової паренхіми, а механічної тканини - зменшується. Товщина вторинної кори та іiі окремих гістологічних елементів у T. platyphyllos і T. europaea виявляє стабільність в умовах техногенного середовища, а у $T$. cordata за дії викидів ТЕС зменшуються як загальна ширина вторинної кори, так і окремих іï складових (м'якого та твердого лубу), причому м'якого лубу суттєвіше. Ширина деревини стебла на забрудненій ділянці зменшується у T. platyphyllos, не відрізняється від контролю у T. europaea та відкладається нерівномірними шарами у $T$. cordata. Радіус серцевини за дії фітотоксикантів знижується в усіх досліджених видів.

Збільшення загального радіуса первинної кори, зокрема, ширини корка та корової паренхіми в усіх досліджених видів, а також підтримання стабільних розмірів коленхіми, твердого та м'якого лубу у T. platyphyllos i T. europaea, а в T. europaea - також і деревини, ми вважаємо, пов'язане із функціонуванням у тканинах даних видів лип в умовах стресу адаптаційних механізмів, кінцевим результатом яких, зокрема, $\epsilon$ зміни 
анатомічних параметрів стебла, які можуть забезпечити певну толерантність рослин у техногенному середовищі. Разом із цим, зменшення ширини коленхіми, твердого лубу, м'якого лубу та нерівномірний розвиток шару деревини по радіусу кільця у $T$. cordata у сукупності може зменшувати механічну міцність стебла, порушувати пересування розчинів органічних речовин і елементів мінерального живлення по системі спеціалізованих провідних тканин, i, таким чином, підвищувати вразливість рослин даного виду на техногенних територіях.

За сукупністю анатомічних характеристик стебла дворічного пагона із досліджених видів більшу чутливість до впливу техногенних емісій виявляє T. cordata, толерантність - T. platyphyllos і T. europaea.

Розміри гістологічних елементів стебла дворічного пагона, які суттєво збільшуються за дії викидів ТЕС (ширина первинної кори, ширина корка), рекомендуємо використовувати як чутливі тест-параметри в моніторингу стану довкілля в умовах техногенезу. Інформативними тест-об'єктами за ними є T. platyphyllos i T. cordata.

\section{Бібліографічні посилання}

Alekseev, A.S., 1990. Kolebanija radial'nogo prirosta v drevostojah pri atmosfernom zagrjaznenii [Fluctuations of radial increment in stands at atmospheric pollution]. Lesovedenie 9(1), 82-86 (in Russian).

Bessonova, V.P., Jusypiva, T.I., 2001. Semennoe vozobnovlenie drevesnykh rasteniy i promyshlennyie pollutanty $\left(\mathrm{SO}_{2} \mathrm{i}\right.$ $\mathrm{NO}_{2}$ ) [Seed regeneration of woody plants and industrial pollutants $\left(\mathrm{SO}_{2}\right.$ and $\left.\mathrm{NO}_{2}\right)$ ]. Zaporizhya University Press, Zaporizhya (in Russian)

Bobyliov, Y.P., Brygadyrenko, V.V., Bulakhov, V.L., Gaichenko, V.A., Gasso, V.Y., Didukh, Y.P., Ivashov, A.V., Kucheriavyi, V.P., Maliovanyi, M.S., Mytsyk, L.P., Pakhomov, O.Y., Tsaryk, I.V., Shabanov, D.A., 2014. Ekologija [Ecology]. Folio, Kharkiv (in Ukrainian).

Capuana, M., 2011. Heavy metals and woody plants - biotechnologies for phytoremediation. iForest 4, 7-15.

Cudin, P., 1996. Degradation and restoration processes in crowns and fine roots of polluted montane Norway spruce ecosystems. Phyton 36(3), 69-76.

Dyrenkov, S.A., Savickaja, S.N., Lukomskaja, K.A., Bogdanov, E.V., 1986. Bioindikacija vozdejstvija vybrosov v atmosferu na lesnoj massiv [Bioindication of emissions impact into air in forestland]. Obshhie Problemy Biocenologii 2, 29-31 (in Russian).

Erofeeva, E.A., 2014. Dependence of drooping birch (Betula pendula) and lime tree (Tilia cordata) relative seed production as a new seed production index on the intensity of motor traffic pollution. Adv. Environ. Biol. 8(13), 282-286.

Faly, L.I., Brygadyrenko, V.V., 2014. Patterns in the horizontal structure of litter invertebrate communities in windbreak plantations in the steppe zone of the Ukraine. J. Plant Prot. Res. 54(4), 414-420.

Grishko, V.M., Mashtaler, N.V., 2009. Vplyv zabrudnennia na formuvannia heneratyvnoi sfery deiakykh vydiv Penstemon Schmidel v umovakh hirnycho-zbahachuvalnoho pidpryiemstva [Pollution affect on formation of generative ability of some of Penstemon Schmidel species under conditions of mining enterprise industrial site]. Plant Introduction 1, 73-79 (in Ukrainian).

Grishko, V.N., Kuchma, V.N., Radzion, D.V., 1997. Anatomicheskoe stroenie pobegov nekotoryh drevesnyh rastenij pri zagrjaznenii okruzhajushhej sredy [The anatomical structure of the shoots of some trees under environmental pollution]. Voprosy Bioindikacii i Jekologii 2(1), 49-54 (in Russian).

Gritzay, Z.V., Denisenko, O.G., 2011. Nasinnieva produktyvnist' derevnykh roslyn v umovakh zabrudnennia dovkillia vykydamy metalurhiinoho pidpryiemstva [Seed production of woody plants in conditions of environment pollution by metallurgical industry emissions]. Visn. Dnipropetr. Univ. Ser. Biol. Ekol. 19(2), 40-44 (in Ukrainian).

Gritzay, Z.V., Jusypiva, T.I., 2004. Vplyv promyslovykh vykydiv koksokhimichnoho pidpryiemstva na vmist vuhlevodiv ta zhyriv u lystkakh derevnykh roslyn [Influence of cokery industry emissions on carbohydrates and lipids content of wood plant leaves]. Pytannia Bioindykatsii ta Ekolohii 9(2), 97-107.

Gupta, S., Bhattacharjee, D., Datta, J.K., Nayek, S., Satpati, S., 2009. Effect of vehicular lead emissions on biochemical constituents of leaves. Poll. Res. 28(2), 157-160.

Jusypiva, T., 2011. Woody undergrowth: Stem anatomy and industrial $\mathrm{SO}_{2}$ and $\mathrm{NO}_{2}$ pollution. NATO Advanced Research Workshop (ARW): "Environmental and food safety in Southeast Europe and Ukraine". Dnipropetrovsk, Ukraine, 57-58.

Jusypiva, T.I., 2005. Vplyv promyslovoho zabrudnennia na histolohichni pokaznyky pervynnoi kory stebla predstavnykiv rodu Fraxinus [The impact of industrial pollution on the histology of the primary cortex of the stem of Fraxinus genus]. Visn. Dnipropetr. Univ. Ser. Biol. Ekol. 13(1), 295301 (in Ukrainian).

Jusypiva, T.I., 2006. Vplyv promyslovoho zabrudnennia na histolohichni pokaznyky tsentral'noho tsylindru stebla vydiv rodu Fraxinus [The impact of industrial pollution on the histology of the central cylinder of the stem species of Fraxinus genus]. Visn. Dnipropetr. Univ. Ser. Biol. Ekol. 14(2), 207213 (in Ukrainian).

Jusypiva, T.I., Gritzay, Z.V., 2014. Vplyv aerohennoho zabrudnennia $\mathrm{SO}_{2}$ ta $\mathrm{NO}_{2}$ na anatomichni pokaznyky stebla Caragana arborescens Lam. [Influence of aero genic $\mathrm{SO}_{2}$ and $\mathrm{NO}_{2}$ pollution on anatomic parameters of Caragana arborescens Lam. stem]. Visnyk Kharkivskoho Universytetu. Seriia Biolohiia 1129(23), 123-128 (in Ukrainian).

Jusypiva, T.I., Korostylova, T.S., 2015. Vplyv tekhnohennoho navantazhennia na fiziolohichni ta tsytohenetychni pokaznyky heneratyvnykh orhaniv predstavnykiv rodu Tilia [Technogenic impact on physiological and cytogenic indices of reproductive organs of Tilia genus representatives]. Visn. Dnipropetr. Univ. Ser. Biol. Ekol. 23(1), 10-14 (in Ukrainian).

Krupenko, L.S., Kapelush, N.V., 2014. Condition of assimilation system Tilia cordata under aerogenic pollution in Zaporozhye City. Questions of Bioindication and Ecology 19(2), 84-90.

Kulagin, A.A., Shagieva, J.A., 2005. Drevesnye rastenija i biologicheskaja konservacija promyshlennyh zagrjaznitelej [Woody plants and biological preservation of industrial pollutants]. Nauka, Moscow (in Russian).

Kulbachko, Y., Loza, I., Pakhomov, O., Didur, O., 2011. The zoological remediation of technogen faulted soil in the industrial region of the Ukraine Steppe zone. Behnassi, M. et al. (eds.), Sustainable agricultural development. Springer Science + Business Media, Dordrecht, Heidelberg, London, New York, 115-123.

Miller, P.R., McBride, J., 1999. Oxidant air pollution impacts in the montane forests of Southern California: The San Bernadino Mountain Case Study. Springer-Verlag, New York.

Neverova, O.A., Legoshchina, O.M., Bykov, A.A., 2013. Anatomy of leaves of Betula pendula (Roth.) affected by air emissions in industrial area of Kemerovo City. Middle-East Journal of Scientific Research 17(3), 354-358.

Pakhomov, O.Y., Gasso, V.Y., Goloborodko, K.K., Poljakov, M.V., Grycan, Y.I., Bulakhov, V.L., Brygadyrenko, V.V., Kljuchko, Z.F., Mezhzherin, S.V., Novicky, R.O., Pysanec, Y.M., Pljushh, I.G., Ponomarenko, O.L., Puchkov, O.V., Radchenko, V.G., 
2011. Chervona knyga Dnipropetrovskoi oblasti. Tvarynnyj svit [The red book of Dnipropetrovsk region. Animals]. New Print, Dnipropetrovsk (in Ukrainian).

Permjakov, A.I., 1988. Mikrotehnika [Microengineering]. MGU, Moscow (in Russian).

Petrova, S., Yurukova, L., Velcheva, I., 2014. Possibilities of using deciduous tree species in trace element biomonitoring in an urban area (Plovdiv, Bulgaria). Atmospheric Pollution Research 5, 196-202.

Ponomar'ova, O.A., Bessonova, V.P., 2009. Vplyv rostu lyp u lunkakh $\mathrm{v}$ asfal'ti prydorozhn'oi zony na pokaznyky asymiliatsiinoho aparatu [The influence of growth $T$. cordata and $T$. platyphyllos in hole into the asphalt of roadside zone of size the morphometrix indicators of assimilation system]. Questions of Bioindication and Ecology 14(2), 55-62 (in Ukrainian).

Riikonen, J., Percy, K.E., Kivima, M., Kubiske, M.E., Nelson, N.D., Vapaavuori, E., Karnosky, D.F., 2010. Leaf size and surface characteristics of Betula papyrifera exposed to elevated $\mathrm{CO}_{2}$ and $\mathrm{O}_{3}$. Environ. Pollut. 158, 1029-1035.

Sergejchik, S.A., 1984. Drevesnye rastenija i optimizacija okruzhajushhej sredy [Woody plants and optimization of the environment]. Nauka i Tehnika, Minsk (in Russian).

Skärby, L., Ro-Poulsen, H., Wellburn, A.R., Sheppard, L.J., 1998. Impacts of ozone on forests: A european perspective. New Phytol. 139, 109-122.

Smit, Y.H., 1985. Les i atmosfera [Forest and atmosphere]. Progress, Moscow (in Russian).

Striletz, R.O. (ed.), 2014. Ekolohichnyi pasport Dnipropetrovs'koi oblasti [Ecological passport of Dnipropetrovsk region]. Dnipropetrovsk (in Ukrainian).

Veselkin, D.V., 2004. Anatomical structure of ectomycorrhiza in Abies sibirica Ledeb. and Picea obovata Ledeb. under conditions of forest ecosystems polluted with emissions from copper-smelting works. Russian Journal of Ecology 35(2), 71-78.

Надійшла до редколегії 20.09.2015 